\title{
Digital Learning: New Age Tools and the Changing Education Scenario, Trends and Challenges in India
}

\author{
Sailaja Venuturumilli* \\ Ph.D in Management Studies, Ahmadabad, India \\ Prasada Rao Peyyala \\ Director, AMITY Global Business School, Hyderabad
}

\begin{abstract}
"Digital learning is just making sure that if I need a piece of learning while I'm on the job ... I can quickly find that information such as from a podcast or video and integrate it right into the task I'm doing." Don Dequette, executive vice president at New York City-based General Physics Learning Solutions Group.

Earlier, the internet revolution had brought radical changes practically in all spheres of our lives, across various products and service sectors from ordering consumer goods, medicines, food to hiring a cab. Presently this revolution is being witnessed in education system through modern digital learning methods which are disrupting traditional higher education that has altered its pace from a gradually evolving process to strategical to tactical implementation of newer kinds of technologies. However, the degree of implementation in educational institutions depends on government policy that may not match the ever-accelerating speed of technological innovation and this varies from nation to nation. This conceptual study is intended to find the present status of digital learning methods in education, the important factors that are leading to the growth of digital market, and digital training trends in India. The study identifies that growth of digital education in India is due to improved internet connectivity along with adoption of digital payment options and is opening up more opportunities for teachers as well as students. Advanced digital tools are being incorporated by organisations as the most innovative ways for training, assessment and certification programs. It is implicit that digital learning is enhancing current ways of learning by offering more personalized and swift learning solutions through blended or completely online leaning methods using real-time education. While developed countries are well ahead in formulating policies for development in the field of education, India, could capture only a minute percent in private education and hardly has its presence in rural areas and should exploit the enabling capabilities of Information and Communication Technology (ICT) for holistic growth of students to meet the global skills. As digital education is impetus in the present times, traditional learning should leverage the digital technology to enhance the experience of learning and to impart better knowledge in students.
\end{abstract}

Keywords: Information and Computer Technology (ICT), digital education, online learning, internet, smart learning

DOI: $10.7176 / \mathrm{IKM} / 9-10-01$

Publication date: November $30^{\text {th }} 2019$

\section{Introduction}

"The amount of knowledge produced has doubled in few years of span, compelling us to develop new skills to survive, continuing our evolution cognitively" - Aras Bozkurt and Amy Hilbelink.

Earlier, class room learning is the only option to learn, but today along with class room learning, there are various options that includes online learning or e-learning, digital learning, blended learning, distance learning and virtual learning. Digital learning allows learning through the internet and is available in variety of forms depending on the usage of technologies, like computer systems, mobile devices, the degree of participation of instructors and students and nature of the courses. "Education will not be a location anymore, but an activity: a teaching-learning activity. This is the ultimate raison d'être of Information and Computer Technology (ICT) s for education", Haddad Wadi and Draxler (2002). Government policy on online learning is handled in different ways globally depending on the structure and the level of determination to integrate it into the curriculum. "Only digital transformation skills in this sense will enable higher education to keep up with real-world developments by extending contemporary pedagogical methods" says Cerstin Mahlow and Andreas Hediger (2019). "Confidence in the classroom is directly correlated to success in the "real world", Michael Hansen (2017), CEO, Cengage Learning.

The Indian online learning market size in 2016 was USD247 million, comprising 1.6 million users and is expected witness an eight times growth of USD1.96 billion and the current user base will grow at 44 percent CAGR to 9.6 million users by 2021, according to a KPMG report, 2017. Also, it is predicted that the India's online learning market to grow by 15.64 percent and exceed $\$ 48$ billion by 2020 , and is the second largest after the United States. In India, technology's use in higher education is identified by Ministry of Electronics and Information Technology (MeitY) and is supported by ICT with a broad objective to develop tools and technologies to promote online learning for imparting education using communication media. It is being managed by the publicly funded 
Joint Information Systems Committee (JISC), which acts as an advisory committee. The application of digital tools of learning has become a necessity in schools and digital learning is no longer considered a luxury. Presently digital education in India is witnessing a steady growth rate of 25 per cent every year, with a network of more than 1.5 million schools and 18,000 higher education institutes and is expected to reach US\$2 billion by 2020 .

\section{Information and Communication Technologies (ICT) in Education}

"e-Learning is an umbrella term describing any type of learning that depends on or is enhanced by electronic communication online using the latest ICTs", Nagy.A (2004). In education, ICT uses information and communication technology to support, enhance, and optimise the delivery of information. ICT enabled teaching methodologies are being used by the faculty members in class rooms, setting the path to educational institutions, especially in countries like India as the growth is directly connected with technology. ICT is providing education with the help of various devices and technology while cloud-based platforms help students without paperwork. Technology use in education, creates new prospects for curriculum by bringing real-world problems into the classroom for students to explore and solve and help them develop the needed competencies. Also, with innovative deployment of ICT, students can access information whenever and wherever they want, and is being accessed by universities and professors, at homes and hostels through mobiles and computers, in urban as well as rural areas.

\subsection{Evolution of ICT}

The main role of computers during early 1970s and 80s was to teach programming that would develop programming skills for students (Teemu Leinonen, 2005). The computer based training (CBT) with multimedia, with advanced graphics and sound came into existence during 1980s and 90s. The educational motive during the CD-ROMs and multimedia computers phase was to teach people learning and understanding. The raise of World Wide Web using Internet-based training (IBT) using computers in education was seen during 1990's. However during that period, the purpose to promote internet-based training was not educational, it was mainly intended for cost-efficient purposes. The Internet-based training advanced during late 1990's and early 2000 in the form of elearning. Educational institutions and organizations came up with various e-learning solutions while companies engaged dedicated IT managers. Figure. 1 illustrates the four major phases of learning and use of computers, the fifth is the era of social software and free and open content. The present online learning industry took shape as the markets for online e-learning courses and especially for Learning Management Systems (LMS) was created.

\subsection{Use of ICT in Education}

According to Haddad and Draxler (2002), use of technology in education will not have the desired impact when the purpose teaching is for demonstration and when learning is used only for remembering and reciting. They added that technology investment could be cost-effective when both students and teacher work together to improve teaching-learning process in a significant manner. The figure. 2 illustrates the role of teacher and learner and shows that with increase in the number of educational activities and skills, the teacher's and the learner's roles evolve from "provider" to "facilitator" and from "passive" to "active" respectively. ICT can be used as an important tool for delivering quality lectures for the students to understand the subject but not for replacement of the knowledge acquired in the process of interaction with the faculties, Suman Nandy (2018).

\section{Online learning or e-learning}

Today, online learning is emerging in India in more proficient way to instil meaningful education for students from middle class to master's program in remarkable way, allowing students learn skills online. The origin of online learning dates back to early 1800's in the form of distance learning. Introduced by Sir Isaac Pitman's mail courses through distance learning delivered to students in remote locations. It has been around for decades, but it was only since 1960, online learning has started to evolve. Since then, the distance education has taken various forms such as mail delivered instructions, materials in print format, classes over electronic medium, via mobile devices, the content deliver format remaining the same, including the present virtual classes (Moore, 1990). The adoption has seen in academic institutions, corporations training and in military (Fletcher \& Rockway, 1986). The research trends in distance education were observed by researchers between 2009 and 2013 and found that there was a gradual change from distance education to open and distance learning, which became more open as free, easily accessible, or publicly available (Suzan Koseoglu, 2019).

\section{Smart Education}

Smart learning uses modern technology tools to achieve enhanced interactivity in classroom teaching-learning that includes projector, camera, laptop, speaker, white board, wi-fi router and necessary LAN tools. Smart education can be done in a virtual or physical environment or combination of both that supplement the traditional education (Amit Dua, 2018). Smart learning methods allow students to team up with others on virtual learning platforms and participate in online discussion around the world. Smart learning in class rooms uses high speed image sensors 
which can intelligently track and learn the environment and allow for a seamless information control with any type of display with real-time interaction with superior interactive performance. Smart education data and communication tools permit to record student's attendance, examination scores and can be updated the same to the parents, allowing transparency between parents and teachers.

\section{Education scenario in India}

Indian education system includes both formal and informal education, managed by private and public providers (figure.3). The formal higher education is governed by Central Board of Secondary Education (CBSE), Indian Certificate of Secondary Education (ICSE) and state and international boards, with over 1.4 million schools and 227 million enrolled students in 36000 higher education institutes (KPMG report, 2017). India has multi layered formal education that comprises primary, secondary, graduation, post-graduation and diploma courses. India has one of the largest higher educations, governed by university grants commission (UGC) and other professional courses are managed by Medical Council of India (MCI), National Board of Examination (NBE), Bar Council of India and All India Council for Technical Education (AICTE). Informal education comprises pre-primary, vocational education, coaching for various classes, multi-media or technology based education as a substitute for formal education.

\section{Key Drivers of digital learning growth in India}

Recent past has witnessed e-learning as a standard way of learning either with the combination of online and faceto-face approach or as an independent fully functional method. Today, 82 percent of colleges and universities offer several courses online to provide better-quality opportunities for students who can't spend long hours in a lecture hall. To adopt online education, one of the motivational factors for students is the convenience and flexibility and variety of study material.

From the figure. 4 it is evident that there is remarkable rise in the paid user base for online education and is expected to grow in the next few years. The demand for online learning is visibly seen for primary and secondary supplemental education and for reskilling and online certificate courses. The paid user base is expected to grow from the user base of 1.57 million in 2016 to 9.5 million in 2021 at a CAGR of $44 \%$. Some of the key drivers for digital growth are discussed below.

\section{Internet and smartphone penetration}

Rapid evolution of internet, smartphone penetration, handheld computers, tablets and computers has given the scope for $\mathrm{m}$ learning and online learning. While the number of internet users is expected to reach 735 million, the smartphone user base is expected to grow by 470 users by 2021 (KPMG report, 2017).

\section{Access through remote servers}

Access of course materials through remote access servers which is possible with modems and dial-up technologies, allows students to connect telephone networks. Remote connections are made through the use of a network which connects the computer and the device that is used to access it. Remote access software is used to control the remote computer with the help of software.

\section{Digital warehouses}

Online digital warehouses are used for organizing lectures. For example, the student's past test scores from the data warehouse can help educators to respond appropriately to his/her new performance compared to the previous year's tests, allowing them to pay attention to the areas wherever it is needed. Digital warehouses help educators to redesign the lesson plans for the subsequent term, adding more emphasis on additional skills required based on the new test results to better suit his students' needs and helps to design course materials.

\section{Assessment of learning outcome}

Identified as 'adaptive learning', smart education makes use of learning analytics and captures student's motivation and understanding from the information collected from a group of students. By providing continuous improvement against individual learning needs better teaching styles can be crafted to fit the student needs.

\section{Social learning}

Also called as 'social learning', smart education is allowing many students to learn by using mobile phones. As knowledge can be transferred with greater speed, the process of learning adds social dimension as it can also be shared, discussed and debated as well.

\section{Academic management systems (AMS)}

AMS is a comprehensive web enabled tool designed for faculty, students and administrators for smooth handling of college admission process. The process includes student registration, starting from application, selection, and intimation to post admission to handling of course. It is also designed for faculty registration, allocation of courses to the faculty, student attendance, internal assessment, end-semester assessment, and conversion of marks to grades, declaration of results, grade card generation and distribution.

The flipped classroom concept

A flipped classroom is a blend of traditional learning and online by delivering instructional content. This concept 
includes traditional homework carried by students by watching online lectures, collaboration of online discussions, or carrying out research at home while engaging in concepts in the classroom with the guidance of a mentor. In classroom teaching, student activities are limited as they work independently or in small groups on an assigned task designed by the teacher, whereas in a flipped classroom, the instructions may take various forms, either through video lessons prepared by the teacher or third parties.

Flexibility of time

To learn specific skill courses like artificial intelligence (AI) specially trained professionals are required. As the availability of these professionals is a big constraint, e-learning can resolve this problem as students as well as working professionals can pursue online mode whenever they need.

Easy access

The major strength of e-learning is that it can be easily accessed from any place and at any time, at their convenience without any time restriction. Safe electronic environment and official recognition for digital signatures and e-transactions has made e-learning more accessible for online education.

Quality education

Access to quality education with personalized content to the students by experienced professionals by engaging with quizzes and challenges, is making the e-learning experience more entertaining.

Significant increase in disposable personal income

Rise in disposable income and easy access to credit cards comprising by huge middle class has accelerated the growth of digital learning in India.

\section{Affordability}

Online courses for undergraduate and post graduate level are more affordable than traditional college programmes. With the advancements of e-learning resources, students can access quality education at a much lower cost and they can focus on gaining employable skills, by discovering their true interests in more efficient way, in terms of time and money they spend.

Demand for online courses

As e-learning is becoming ever-more widespread, there is demand for online educators to meet the needs of diverse learners by designing learning experiences more participative. The rise in number of online courses like the khan academy, edx, tutor, pearson, conveys that there is a huge demand for off-the-classroom learning facilities.

Multimedia technologies

Availability of multimedia teaching aids like, LCD projectors in class rooms, smart classrooms and internet enabled computer systems has made e-learning more accessible. Effective utilization of audio visual aids enhances the learning experience while e-journals and e-books in digital library are being provided in educational institutes through proxy server in the campuses.

Skill upgradation

The domestic education industry in India has English speaking faculty who can up-grade skills, introduce new products that can be achieved with lower costs of human capital when compared to developed countries.

\section{Low costs}

Costs associated with bandwidth are much less when compared to the costs of infrastructure for new buildings, chairs, desks and blackboards at universities and colleges. Also, online learning can reduce the economic burden on students, as it reduces traveling expenses and allows for flexible timings.

\section{Conventional model not able to enroll additional capacity}

Keeping in view the increasing population in India, the existing conventional brick-and mortar educational system is not equipped to meet the additional capacity. Online learning or e-learning can supplement the conventional model, and bridge the gap to a considerable extent.

\section{Indian government's digital friendly policies and its initiatives}

To promote education and improve literacy through e-learning and transform into digitally empowered society, Indian government has taken up certain measures with the support of ICT. Several programmes as 'Digital India' and 'Skill India' were launched by the ruling government to create a knowledge based society with an aim to implement three principles 'access, equity and quality' under the education policy. To make administrative processes more convenient, transparent and fully accountable, the government has initiated measures that are discussed below.

$>$ e-Education with an aim to connect all schools with broadband and free wifi and develop pilot Massive Online Open Courses (MOOCs)

$>$ Nand Ghars are network of 'modern Anganwadis', designed to address the challenges faced by 13.71 lakh anganwadis in India. They were launched with an aim to improve pre-primary education by interactive learning and to build cognitive ability for children.

$>$ 'Swayam', MOOCs based on curriculum taught in classrooms from 9th class till post-graduation and eBasta -school books in digital form, were taken up. 
$>\quad$ MeitY has been financially supporting research and development (R\&D) projects in the area of e-learning at various academic educational institutes, R\&D Labs, HRD projects and for faculty training.

$>$ Ministry of Human Resources and Development (MHRD) and state skill development bodies like Andhra Pradesh State Skill Development Corporation (APSSDC) have started uploading lectures online so that they can be easily accessed by students whenever they need.

$>$ e-governance projects like e-Mitra project (Rajasthan), e-Seva project (Andhra Pradesh) for providing government services, exchange of information, transactions, integration of previously existing services and information portals.

$>$ IT for jobs teach young people the skills needed for IT and IT-enabled jobs

$>$ National Optical Fibre Network (NOFN) aims to expand broadband connectivity and faster network.

\section{$>$ Future Initiatives}

Government of Gujarat proposes to introduce the smart education, in secondary schools with "Smart

Class" concept to enhance classroom interactivity process. Also, the government has initiated

framework in new areas in e-learning for projects for quality assessment and other areas.

\section{Digital training trends}

The growth of new technologies like augmented reality, micro learning, adaptive learning and massive open online courses (MOOCs) coupled with automation of skills, and globalization have changed the training methods. Digital training is making learners' better experience while conveying its importance. Some of the trends in the digital learning methods are discussed below.

\section{Augmented Reality (AR) and Virtual Reality (VR)}

AR and VR provide experiential real-world training setups and make it exciting for learners. General Motors has used AR to launch videos, PowerPoint presentations, PDFs and quizzes on some of its cars to train salespeople, using their own smartphones. These learning skills help learners to tackle real world situations while they go through the process with a realistic experience. These technologies are specially used in manufacturing or operation of complex machinery, architecture and oil and gas industries and are especially used in medicine when training in high-risk areas, such as complicated surgical procedures.

\section{Customized Content}

Digital platforms collect data from the users, helps to train managers determine the skills needed by employees and the kind of learning needed. It helps managers discover the specific areas where employees need improvement. As this information is gathered at the individual level to discover the learning needs of each employee and creates a tailor-made learning plan for each individual, this customized learning helps them enhance their skills and knowledge.

\section{Micro learning}

This trend of learning uses short bursts of information usually through videos, podcasts that can be created quickly and need not have studio-production quality. Micro learning is more useful for bank managers, employees at workplace to use online learning to review, for few minutes for the products or discounts available to the bank's customers and allows employees to access information on mobile devices in the form of animations or videos even when they are walking between meetings.

\section{Adaptive learning}

Adaptive learning uses technology in real time and customizes the presentation of course material in response to the students' performance. The advanced tools collect specific information about individual students' behaviour based on the accuracy of the students' answers, his confidence in the answers given and the time the student takes to answer questions. The tool then responds to each student by changing the learning experience to better suit that student's needs, based on their unique and specific behaviours and answers. The platform makes use of a series of algorithms to adjust the presentation of the course material to create in a linear and logical manner.

\section{Massive Open Online Courses (MOOCs)}

MOOCs are web-based classes that provide instructor-led experience and allow higher learner satisfaction. Available in academic training for employees in the form of assignments, lecture topics; students accumulated points, these tools provide strong form of training to develop new skills and to advance careers.

\section{Gamification}

Gamification involves game theory and game mechanics and acts as a motivator for learners across different stages of education and training to solve problems and to increase their performance. It adds an element of fun, transparency, and competition to the course. Popularity of gamification started specifically in primary and secondary supplemental education, as it combines games, simulation and videos to children. It is currently employed world-wide for enhancing engagement of learners and many organisations are choosing gamification solutions to up-skill their employees for training.

Mobile Learning

The development of e-learning authoring tools and courses are easily adaptable to mobile devices. An authoring 
tool is software that allows trainers to create and arrange content based on the technical expertise, whether to produce a simple content or sophisticated learning experiences, the cost involved and other factors, into a standardized course structure that can be exported to different multimedia types.

\section{Challenges for digital implementation in India}

India has been progressively making advancements in terms of digital technology and enhancement of knowledge base with the existence of many institutions offering digital technology solutions with qualified and trained manpower. However, there are certain issues still need to be addressed for smooth technology implementation for digital education. Some of the challenges are discussed below.

\section{Initial Expenses}

Costs associated during the initial implementation of technology and data transmission are high when compared to the long term the costs involved in support and maintenance of data and infrastructure.

\section{Limited government policies}

Higher education through e-learning has limited support from government in terms of policies laid and has limited control on quality of course content and assessment.

\section{Security and authorization}

In digital learning, issues like failure of security and authorization, poor bandwidth connectivity, verification of student credentials and other technical problems need to be addressed.

\section{Unwillingness to change}

With traditional learning methods still dominant, transformation to digital learning might cause psychological effects for the faculty. Issues like unwillingness to use technology, lack of knowledge in computers need to be addressed accordingly.

\section{Need for the right combination of digital learning resources}

In order to participate in the digital learning process, digital learning resources should incorporate a right combination of processes such as online access to reference materials, instructor led training, mentoring by experts, as well as other information resources.

\section{Digital Literacy}

Digital literacy is essential to engage digital education particularly in remote locations as India has a diverse and dispersed learner group. Also, translation in local languages is required to deal with local issues and cultural differences and is essential to fully realize the benefits of these new technologies.

\section{Migration of talent people}

Digital technology educators need to build deeper technology understanding and capabilities at all levels of their teaching process, as most of the talented people in India migrate and rarely return.

\section{Access for latest devices and technology and understanding gap}

Educators should provide software used by the majority of the learners. Also, the learners must provide instructions about the learning process at every stage, benefits of the program and make sure ensure that they complete the respective courses, in order to get feedback to make necessary measures.

\section{Right to education for all}

The rural areas of India are still far behind, as quality of education and facilities are below average and outdated. According to right to education act (RTE) in India, education is a fundamental right of every child. According to Dr Ginu George "the smart education, which is an education strategy initiative by government for smart cities as technology enhanced education is yet to transform education across all sectors of students" (Akash, 2018).

Social media engagement

Apart from establishing social and emotional support, providing interactions with others and access to health information, social media platforms may lead to potentially unwanted effects, particularly among young generation. "social grooming" behaviors such as commenting on friends posts, vising and "liking" were linked to 'body image' concerns (Kim and Chock 2015).

\section{Optimal utilization of technology}

While use of technology has many benefits like allowing students with better presentation skills and integration of social media, students at the same time should be taught how to use it effectively and safely.

\section{Parental monitoring}

Parents should interact with children with regular discussions, particularly with young children and educate about the risks involved in the digital world and how to protect themselves.

\section{Conclusion}

The rapid rise of the internet and digitisation has made online learning and smart learning more instantaneous and transparent process. While students are using the technology for more in-depth research on the subjects of their interest, educators and professionals are looking for improved versions of e-learning modules to meet ever changing needs of students. E-learning has been greatly beneficial to students and educators due to its flexibility, 
cost reductions, and overall enhanced experience provided by the features such as gamification, a concept, used to motivate students by using game elements in learning environments. "Interactive and gamified digital content that is tailored for individual students can improve retention and learning outcomes by making instruction more effectively"- McKinsey \& Company (2019). At the same time, the learning experience differs from various elearning educational platforms. Many start-ups are emerging in the online space, especially for students from kindergarten to class 12, to develop skilling and for certification courses. India being a population dense country with numerous languages, handled by different state governments, it is more difficult to provide a coherent national online learning policy that covers various existing curriculums.

Though India is the second largest market for e-learning after US, there is still a lot of potential for further development in the education system. "Education, healthcare, and agriculture, with low levels of digitisation at present, have the potential to create significant economic value by 2025"- McKinsey \& Company (2019). Lack of availability of teachers (MHRD survey, 2017) in states such Bihar, Kerala as well as Jammu and Kashmir account for about four lakh distance education enrolments (KPMG survey). Government policies should ensure that more students graduate with high quality degrees to compete in global workplace. In order to achieve this, digital technology should integrate with curriculum from elementary and secondary education, and ensure that students have technology connectivity and access for various courses along with affordability. So far, only 10 percent of private schools have adopted multimedia classroom teaching and hardly noticeable in government schools. Digital technology can provide a powerful opportunity to address absenteeism and to enroll children who are not going to school and can improve learning outcomes. The Indian government initiative through smart schools, should reach rural areas with latest teaching methods to provide quality education and cultivate creativity among students and make teaching-learning more pleasurable.

Finally, digital educators and parents should teach young students to use right technology when it is needed most, and use minimum tools when needed, as this will allow them to think more creatively. Creating awareness among students for proper use of technology with discipline and individual effort is important as it can increase their focus and confidence. Many parental control apps are available, like the number of hours a child can access internet and so on, and it is always better to create awareness for the child to use technology appropriately. As ICT became indispensable in education and emerged as an essential component, the real success in education can be realized when traditional classroom learning and online interaction are combined.

\section{References}

Amit Dua (2018), "Smart education is more than just advanced learning methods", https://yourstory.com/2018/05/smart-education-advanced-learning

Akash (2018), "Need for smart schools in rural areas", by Dr Ginu George (2018), Assistant Professor, Department of Commerce, Kristu Jayanti College, Bengaluru, for Elets News Network (ENN), retrieved from https://digitallearning.eletsonline.com/2018/12/need-for-smart-schools-in-rural-areas/

Aras Bozkurt and Amy Hilbelink (2019), "Paradigm Shifts in Global Higher Education and e-learning: An ecological perspective, Special Issue: Paradigm Shifts in Global Higher Education and eLearning; e learn magazine, where Thought and Practice meet", retrieved from https://elearnmag.acm.org/featured.cfm?aid=3329487

Cerstin Mahlow and Andreas Hediger, (2019), "Digital Transformation in Higher Education-Buzzword or Opportunity? Special Issue: Paradigm Shifts in Global Higher Education and eLearning" retrieved from https://elearnmag.acm.org/archive.cfm?aid=3331171

Don Dequette, executive vice president at New York City-based General Physics Learning Solutions Group, retrieved from https://www.shrm.org/resourcesandtools/hr-topics/organizational-and-employeedevelopment/pages/4-digital-training-options-for-workplace-learning.aspx

Fletcher, J. D., \& Rockaway, M. R. (1986), “Military Contributions to Instructional Technology. New York, NY: Praeger.

Haddad Wadi and Draxler (2002), “Technologies for education: potentials, parameters, and prospects”, Corporate author: Academy for Educational Development (USA), retrieved from https://unesdoc.unesco.org/ark:/48223/pf0000119129

Kim, J. W., \& Chock, T. M. (2015), "Body image 2.0: Associations between social grooming on Facebook and body image concerns. Computers in Human Behavior," 48, 331- 339.

KPMG (2017), online education in India:2021, retrieved from https://assets.kpmg/content/dam/kpmg/in/pdf/2017/05/Online-Education-in-India- 2021.pdf

Laurie Rowell (2010), "How Government Policy Drives e-Learning", e learn Magazine, where thought and practice meet, October, 2010 Retrieved from https://elearnmag.acm.org/archive.cfm?aid=1872821

McKinsey \& Company (2019), "Digital India: Technology to transform a connected nation"

MHRD (2017), retrieved from http://www.aishe.gov.in/aishe/home

Moore. (1990), "Recent contributions to the theory of distance education. Open Learning, 11- 14. 
Nagy.A (2004), “e-Learning. E-Content Report 6”, ACTeN. 2004.

Suman Nandy, Founder of "ePaathsala'(2018), "This is how ICT has helped in the evolution of education industry", India today web desk, https://www.indiatoday.in/education- today/featurephilia/story/ict-evolution-ofeducation-industry-1387634-2018-11-13

Suzan Koseoglu, (2019), "A Commentary on the Paradigm Shift Toward Openness in Higher Education, Special Issue: Paradigm Shifts in Global Higher Education eLearning”, https://elearnmag.acm.org/featured.cfm?aid=3331170

Teemu Leinonen (2005), "(Critical) history of ICT in education - and where we are heading?" retrieved from https://teemuleinonen.fi/2005/06/23/critical-history-of-ict-in-education-and-wher we-are-heading/

[1]Figure.2 Retrieved from ilite's blog, report by Google and KPMG, 2017 https://ilite.wordpress.com/2017/06/21/indian-online-education-market-to-touch-1-96- $\quad$ billion-by-2021report-by-google-kpmg/

[2] http://www.aurumequity.com/the-online-education-industry-in-india-present-and- future/

[3] http://www.businessworld.in/article/E-Learning-Is-Transforming-The-Face-Of-Education-In-India/01-122018-164717/

[4]https:/www.indiatoday.in/education-today/featurephilia/story/what-is-e-learning-here-s-how-it-can-benefitengineering-students-1278990-2018-07-06

[5]https://www.shiksha.com/mba/articles/online-education-in-india-trends-future-prospects-blogId-14763

[6]https://indiamicrofinance.com/data-entry-india.html

[7] eLearning Methodologies: A guide for designing and developing eLearning courses

[8]https://elearningindustry.com/4-best-practices-delivery-digital-learning-resources

[9]https:/www.accenture.com/t20170203T040028Z_w_/be-en/_acnmedia/PDF-5/Accenture-DigitalLearning-Report-and-How-To-Guide_Full.pdf

[10]https://yourstory.com/2018/07/e-learning-indian-education/

[11]https://stories.linways.in/ict-enabled-education-d190bcc91bf0

[12]http://vikaspedia.in/education/teachers-corner/national-teacher-platform

[13]https://yourstory.com/2018/05/smart-education-advanced-learning

[14]http://citeseerx.ist.psu.edu/viewdoc/download?doi=10.1.1.202.431\&rep=rep1\&type=pdf

[15]https://elearnmag.acm.org/archive.cfm?aid=1872821

[16]e-school news, today's innovation in education (2017), https:/www.eschoolnews.com/2017/01/02/hotedtech-trends-2017/3/

[17]https://www.nap.edu/read/9853/chapter/13

Figure 1.

Major phases in the history of learning using computers

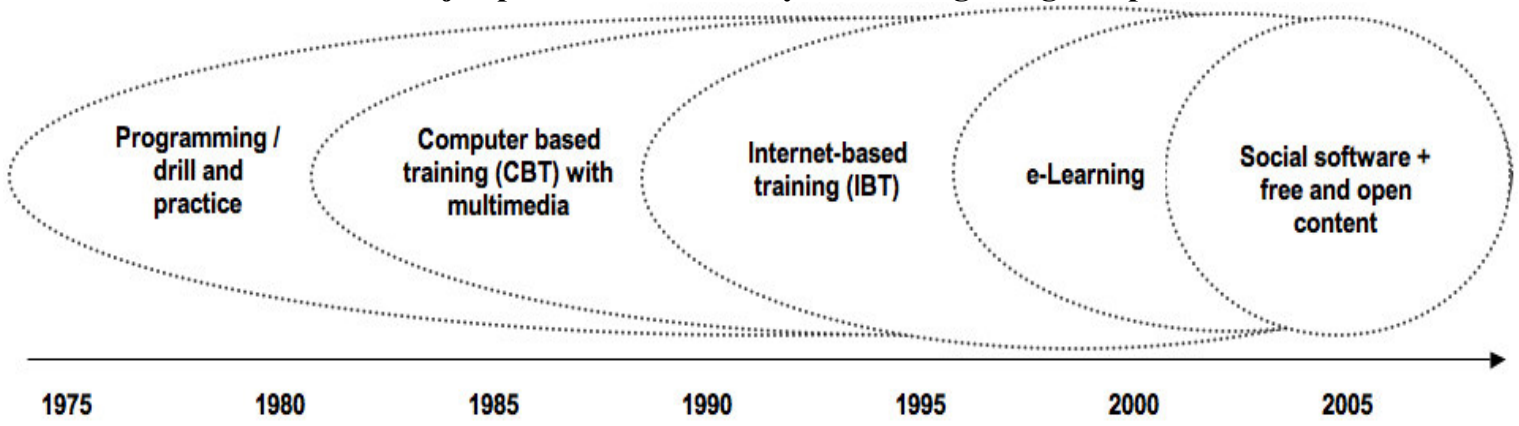

Source: Teemu Leinonen (2012)

https:/teemuleinonen.fi/2005/06/23/critical-history-of-ict-in-education-and-where-we-are-heading/ 
Figure.2

Use of ICTs for different roles of teachers and learners

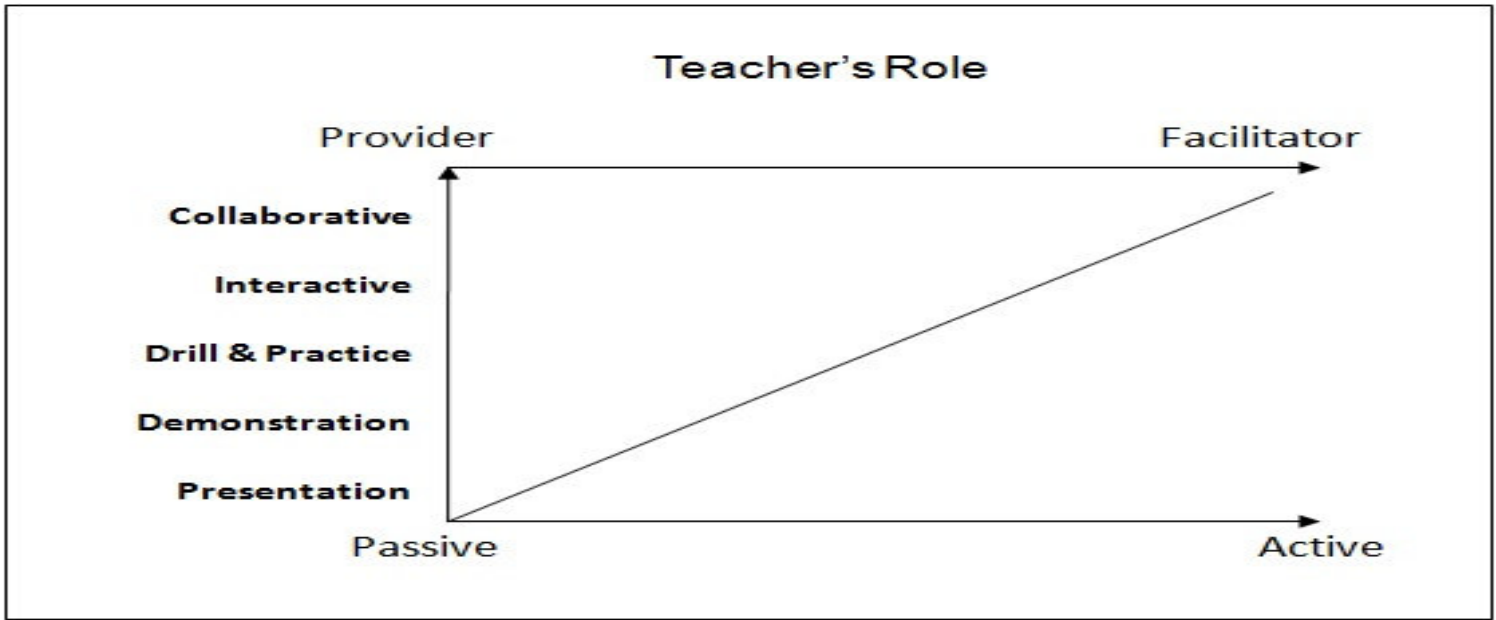

Figure 2 Source: Wadi D. Haddad and Alexandra Draxler $(2002,13)$

Figure.3

Education Landscape in India

Education Landscape In India

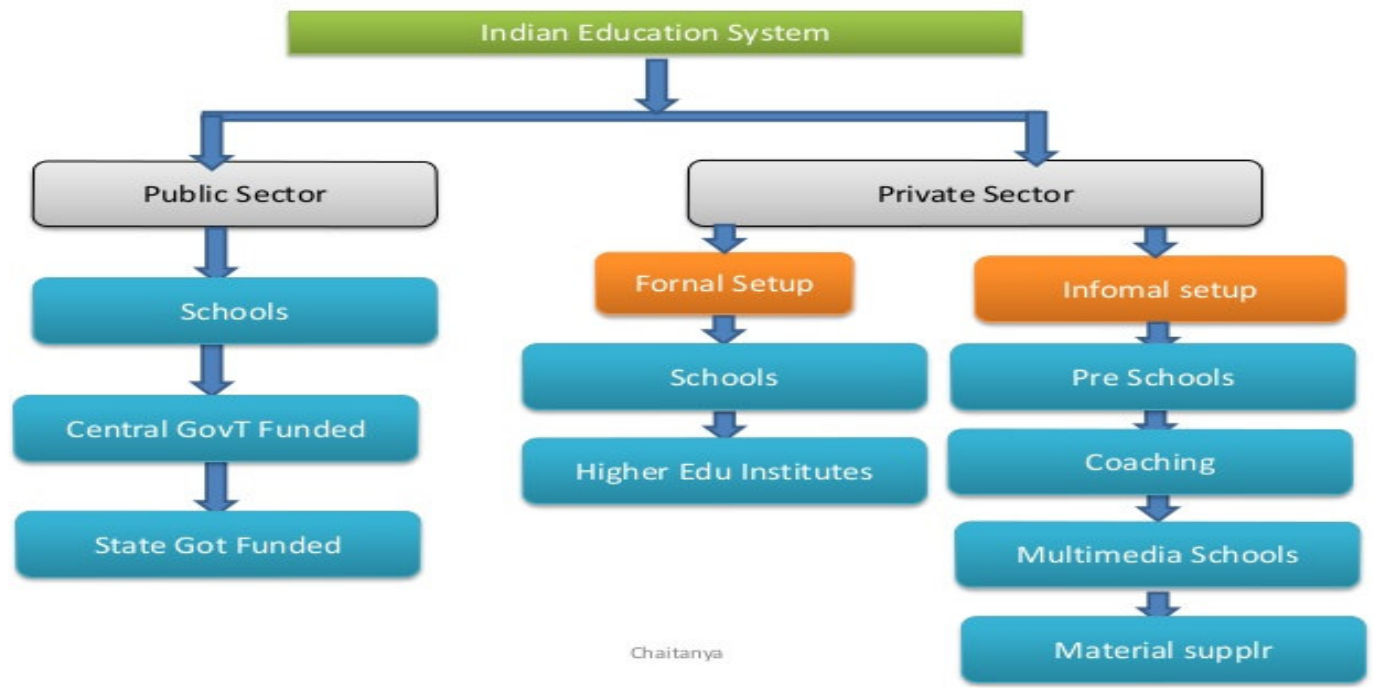

Source: https://www.slideshare.net/03071985/education-landscape-in-india 
Figure. 4

Online education market in India

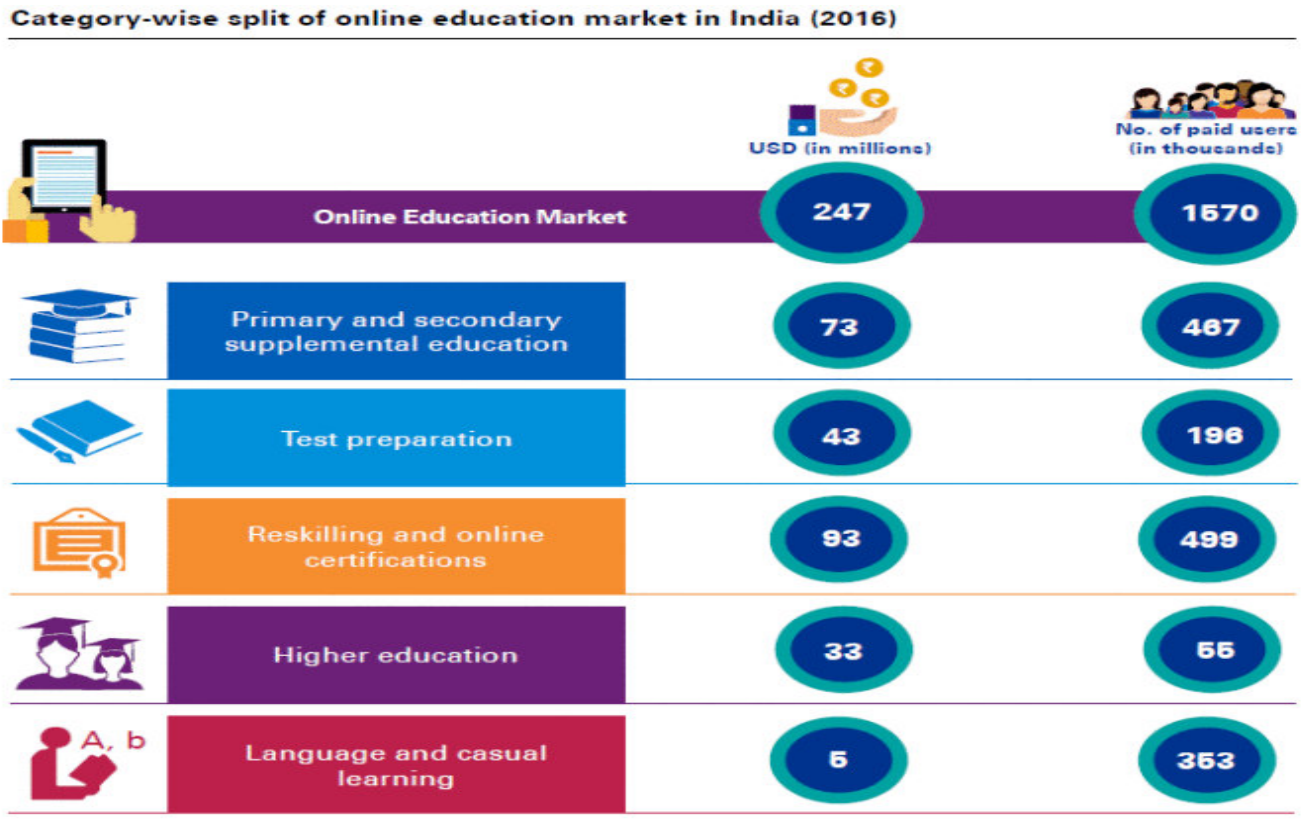

Figure.4 Source: Google and KPMG, 2017

\section{Corresponding Author}

Sailaja. V is presently working as a consultant in Business Management Studies. Recently she was awarded Ph.D in Management Studies from JNTU Kakinada, India. She has over 12 years of teaching and 5 years of industry experience. Her research interests are in the areas of technology adoption and innovation in retail practices. Her research papers have been published in conference proceedings at BITS Pilani, India, journals such as European Journal of Business Management and African Journal of Business Management, Journal of Economics and Business Research.

\section{Second Author}

Prasada Rao. $\mathbf{P}$ is the Director at Amity Global Business School, Hyderabad, India with over 35 years of experience; 10 years of experience in IT and Telecom industry, remaining 25 years in teaching, academic administration, management development programs and research and consultancy. He is associated with Editorial Boards of several Journals as Reviewer such as ICFAI and IPJ. His research interests are in the areas of Agri services, marketing strategy and strategic management. He has published in variety of journals such as, ICFAI, European Journal of Business Management, and African Journal of Business Management, Journal of Economics and Business Research. 